\title{
Hypochlorite accident: fortunately a rare case in paediatric patients
}

\author{
Mariana Leitão Santos, Helena Silva, Ariana Afonso, Cláudia Patraquim
}

Pediatrics, Hospital de Braga, Braga, Portugal

\section{Correspondence to}

Dr Mariana Leitão Santos; marianamltsantos@gmail.com

Accepted 4 February 2020

\section{DESCRIPTION}

Sodium hypochlorite is a commonly used endodontic irrigant. It has the ability to dissolve necrotic and vital pulp tissue. It is a disinfectant against broad-spectrum Gram-positive and Gramnegative bacteria, fungi, spores and viruses; causes biosynthetic alterations in cellular metabolism and phospholipid destruction; forms chloramines that interfere in cellular metabolism; and causes oxidative action with irreversible enzymatic inactivation in bacteria, and lipid and fatty acid degradation. Although it is regarded as safe for endodontic use, the cytotoxic results of accidents must be highlighted; if it comes into contact with vital soft tissue outside the canal system, it can produce serious toxic effects such as haemolysis, ulceration and tissue necrosis. ${ }^{12}$ A hypochlorite accident is defined as inadvertent injection beyond the apical foramen. It is a very rare situation but can be lifethreatening. ${ }^{2}{ }^{3}$ Pain is a hallmark of tissue injury during the irrigation, when an accident happens. Swelling of the surrounding mucosa, subcutaneous tissue and skin occurs a few hours later. ${ }^{12}$ Airway compromise should be excluded. ${ }^{1}$

A previously healthy, 7-year-old female child was referred to the emergency department for left facial oedema and haematoma after an endodontic treatment. During root canal treatment of a primary tooth (first left upper molar), the patient felt serious pain as the dentist did the irrigation of hypochlorite and at discharge was advised to apply ice and to initiate treatment with ibuprofen and antibiotic. During the day, she developed left facial oedema and haematoma, with progressive worsening and associated pain, and started food refusal. On the same day, she presented to a private hospital, started intravenous hydrocortisone and was transferred to our hospital for a paediatric evaluation. She had important oedema and haematoma of the left face (middle and lower third), inducing suppression of the left nasogenian fold and partial occlusion of the left eye (figures 1 and 2), and had difficulty opening her mouth; moreover, at oropharynx evaluation,

Check for updates

(C) BMJ Publishing Group Limited 2021. No commercial re-use. See rights and permissions. Published by BMJ.

To cite: Santos ML, Silva $H$, Afonso A, et al. BMJ Case Rep 2021;14:e233206. doi:10.1136/bcr-2019233206

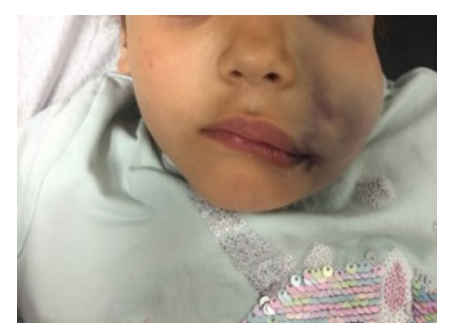

Figure 1 At the day of admission.

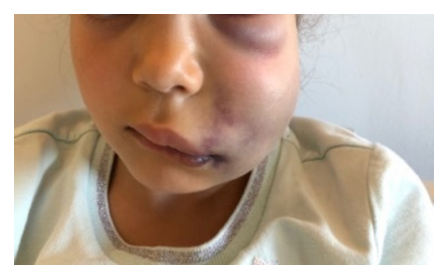

Figure 2 Aggravation of eye oedema and haematoma.

she had left cheek mucosa haematoma. The ultrasound of the swelling area revealed subcutaneous tissue thickening but no abscess. The case was discussed with stomatology, which recommended hospital admission under intravenous antibiotics, corticosteroids and analgesics. She started intravenous amoxicillin/clavulanic acid, clindamycin, methylprednisolone, analgesics and fluids. She went through an ophthalmological evaluation that excluded complication and a second ultrasound, on day 3 of admission, that revealed less thickening of cellular subcutaneous tissue on the left malar region, keeping areas of greater thickening adjacent to the left contour of the lip and the lower eyelid. During hospitalisation, there was a progressive improvement of the facial oedema and areas of haematoma. She was discharged after 7 days, on amoxicillin/clavulanic acid up to 14 days of antibiotic therapy. At the follow-up stomatology consult, 2 months after discharge, she had no sequels.

This was a successful case. However, due to potential side effects of hypochlorite, it is essential that clinicians know how to deal immediately and effectively with any repercussions of an accident. It

\section{Learning points}

Hypochlorite accident is uncommon and defined as an inadvertent injection of sodium hypochlorite beyond the apical foramen that leads to tissue necrosis.

- The diagnosis is based on clinical presentation that includes acute pain, bruising and progressive swelling involving the infraorbital area and mouth angle, haemorrhage from the orifice of the tooth, neurological damage (paraesthesia or anaesthesia), secondary infection and even respiratory compromise.

- It is essential that clinicians know when to use it, are trained to use it, and know how to deal immediately and effectively with any repercussions of an accident. 
is important to recognise the signs and symptoms and to initiate the treatment as soon as possible.

Contributors MLS: idea for the article, literature search and writing of the article. $A A, H S$ and CP: revision of the article; identification and management of the case.

Funding The authors have not declared a specific grant for this research from any funding agency in the public, commercial or not-for-profit sectors.

Competing interests None declared.

Patient consent for publication Parental/guardian consent obtained.
Provenance and peer review Not commissioned; externally peer reviewed.

\section{REFERENCES}

1 Faras F, Abo-Alhassan F, Sadeq A, et al. Complication of improper management of sodium hypochlorite accident during root canal treatment. J Int Soc Prev Community Dent 2016;6:493-6.

2 Patel E, Gangadin M. Managing sodium hypochlorite accidents: the reality of toxicity. $S$ Afr Dent J 2017;72:271-4.

3 Goswami M, Chhabra N, Kumar G, et al. Sodium hypochlorite dental accidents. Paediatr Int Child Health 2014;34:66-9.

Copyright 2021 BMJ Publishing Group. All rights reserved. For permission to reuse any of this content visit

https://www.bmj.com/company/products-services/rights-and-licensing/permissions/

BMJ Case Report Fellows may re-use this article for personal use and teaching without any further permission.

Become a Fellow of BMJ Case Reports today and you can:

- Submit as many cases as you like

- Enjoy fast sympathetic peer review and rapid publication of accepted articles

- Access all the published articles

Re-use any of the published material for personal use and teaching without further permission

\section{Customer Service}

If you have any further queries about your subscription, please contact our customer services team on +44 (0) 2071111105 or via email at support@bmj.com.

Visit casereports.bmj.com for more articles like this and to become a Fellow 